\title{
Assessment of the Impact of External Borrowing on the Economic Growth of the Developing Countries - Nigerian Experience
}

\author{
Adeboye Akanni Akinwunmi ${ }^{1} \&$ Rosemary Bukola Adekoya ${ }^{2}$ \\ ${ }^{1}$ Department of Banking and Finance, Achievers University, Owo, Nigeria \\ ${ }^{2}$ Department of Banking and Finance, Federal Polytechnic, Ado-Ekiti, Nigeria \\ Correspondence: Akinwunmi, Adeboye Akanni, Department of Banking and Finance, Achievers University, P. \\ M. B. 1030, Owo, Ondo State, Nigeria.
}

Received: October 9, 2017

Accepted: February 28, 2018

Online Published: March 6, 2018

doi:10.20849/abr.v3i1.331

URL: https://doi.org/10.20849/abr.v3i1.331

\begin{abstract}
This paper examines the impact of foreign borrowing on the economic growth of the developing nations using Nigeria as a case study. Time series data from 1985 and 2015 were sourced from Central Bank of Nigeria Statistical Bulletin and other related journals. Data sourced were analyzed using Durbin Watson auto correlation to test for the reliability of the data and diagnostic tests such as unit root test (Augmented Dickey Fuller) and Johansen co-integration to test for the non-stationary of the data and long run relationship between the dependent and independent variables. OLS multiple regressions were used as estimation technique to test for the relationship between the explanatory variables and economic growth. The study revealed that there is significant relationship between economic growth, exports, capital investment and debt service payment but external debt and exchange rate have a significant inverse relationship with economic growth. The study concludes that, capital investment, exports and debt service payment have impact on economic growth but external debt and exchange rate do not. Therefore, the study recommends that, purpose of borrowing should be considered important while channeling the borrowed funds and efficient utilization of the funds to solve the purpose by which it was acquired will go a long way to impact growth on the economy of the country.
\end{abstract}

Keywords: foreign borrowing, exchange rate, capital investment debt payment service

\section{Introduction}

All over the world, countries relied on each other on social, political, economic, finance and security grounds and as a result of this self-insufficiency, the countries tends to depend on each other's for survival. It is good to know that, majorly, the developing countries are most vulnerable because of their characteristics. According to Oloyede (2002) developing countries are countries characterized with less developmental growth, low per capital income, increase in poverty and unemployment rates, high budget deficits, high inflation rate, low savings and investment, underutilization of natural resources, lack of efficient industries and enterprises, lack of capital and technology, backward human resources, existence of infrastructural gap to mention but a few. All these factors are responsible for the growth decadence that most developing countries are facing and since they do not have sufficient resources to solve these problems, most of them resort to foreign borrowing for sustainability.

Every government especially the developing countries borrows to achieve dual major macroeconomic goals such as higher investment or higher consumption i.e. education and health or to finance transitory balance of payment deficit, to lower nominal interest rates abroad, lack of domestic long term credit or to circumvent hard budget constraint. Thus economy indulges in borrowing to boost economic growth, reduce poverty and limit the suffering of people from macro-economic instability polices that distort economic incentive or sizeable adverse shocks (Soludo, 2003; Shehu and Aliyu 2014). As a result of this, growth is likely to increase and allow for timely debt payment. When the circle is maintained for a period of time, growth will affect per capital income positively which is a prerequisite for poverty reduction. The predictions are known to hold even in theories based on the more realistic assumption that countries may not be able to borrow freely because of the risk of debt denial (ibid).

In Nigeria, the quest for rapid growth and development in a resource constrained economy characterized by low domestic savings and investment, low tax revenue and meager foreign exchange earnings inspired foreign 
borrowing to finance critical investment projects that will bring about a rapid economic growth to the country. It is important to know that, the promulgation of the government promisory notes ordinance for the purpose of raising authorized loans in 1960 effectively formalized foreign borrowing as an official policy in Nigeria (Falegan, 1978). In addition, 1962 External Loans Act was enacted sanctioning the contracting of external loans for development programmes and transfers to the regional governments. In the aftermath of the civil war, the federal government also promulgated the 'external loan rehabilitation, reconstruction and development decree' which authorized the commission to raise loans outside Nigeria to facilitate rehabilitation, reconstruction and development programmes in war ravaged areas and to be extended as loans to state governments ( ibid)

Unfortunately, since the foreign borrowing became an official policy in Nigeria, there has been a sharp increase in the rate at which the country borrows from the developed countries and private international financial institutions for the purpose of alleged economic growth. Although, foreign borrowing at the first decade of political independence in Nigeria i.e between 70's and 80's was minute, the rate of interest was concessionary, the maturity of the loan was long term and the source was usually bilateral in nature (Ayadi and Ayadi, 2008)

As revealed by the CBN (2014), foreign borrowing started to grow in an arithmetical rate from 1985 to 1998 i.e from (N41billion to N633billion) but sadly between 1999 and 2004, foreign borrowing grows in a geometrical rate from N633billion in 1998 to N2, 577 billion in 1999 and it continues to grow astronomically like that to N4, 890billion in 2004. Between 2005 and 2007, sizeable chunks of the Nigeria external debt were paid or offset and forgiven through the then minister of finance under the administration of Olusegun Obasanjo and this brought the total reduction in the outstanding external debts of the country from N4, 890 billion to N431billion. Unfortunately, the country resumed the act of the borrowing in 2008 which has made the country to remain indebted to the international financial institutions to the tune of N1, 631billion as at 2014(CBN Statistical Bulletin, 2014).

Foreign borrowing is meant to enhance economic growth but the effect has not really been felt in Nigeria as expected. Consequently, amidst the available resources, the country has continue to record high rate of insecurity and militancy due to high rate of unemployment among the active labour force, high rate of poverty, lack of infrastructure, high rate of inflation and many others. It is on this basis that the study examined foreign borrowing and its impact on the economic growth of Nigeria as a case study from 1985 to 2014.

\subsection{Statement of the Problem}

In Nigeria, foreign borrowing was resorted to, for the purpose of bridging the infrastructural gap that has been the bane behind the economic growth but despite the fact that the country continues to accumulate much debt from both international private and public developed institutions even internally. The required growth expected is yet to be attained rather, the country continue to record high rate of unemployment among the active labour force, high poverty rate, low per capital income, inadequate power and water supply, inadequate social amenities, bad road network, high budget deficit, high rate of corruption in all government parastatal etc. This position was corroborated by the Minister of Finance in person of Kemi Adeosun when she said in her statement that "Nigeria problems is as a result of infrastructural gap in the country of which all efforts must be directed towards bridging the accumulated infrastructural deficit in the economy so that the required growth and development can be achieved". Also, Nwankwo (2016) expresses that "When you are in the kind of economic situation the country has found itself, you have to decide where you want to start addressing the problem. The most critical point to start is to deal with infrastructure problem in the country. In the study of Olufemi, (2016) and Edun et al (2013) submitted that the bane of Nigeria's underdevelopment has been attributed to the lack of infrastructural facilities, wrong policy frameworks, hostile environment, backwardness in technology, problem of unemployment and over-dependence on imported products amongst other factors. Based on the above position, the question then becomes, despite the huge borrowing of the country, why has borrowing not accelerate the pace of growth in Nigeria. Why does Nigeria continue to record and give beautiful reports on economic growth against the physical attendance of the growth known to the world? Amidst of the beautiful GDP position of Nigeria, why is the country still having wide infrastructural gap? These and many other questions are what the study wishes to provide solution to.

\subsection{Research Objective}

The main objective of this study is to assess the impact of external borrowing on the economic growth in Nigeria Specifically; the study will examine the relationship among the following variables external debt, capital investment, debt payment service, exports and exchange rate on the economic growth in Nigeria. 


\subsection{Research Hypotheses}

The hypotheses for this study are stated in line with the research objectives

\section{Literature Review}

\subsection{Conceptual Review}

In the literature, foreign borrowing and external debt has been used concurrently. It is believed that, the total amount borrowed is synonymously to what you owe. Therefore, in this study foreign borrowing and external debt will be used interchangeably. Arnone et al (2005) described external debt as that part of a country's debt that was borrowed from foreign lenders including commercial banks, governments or international financial institutions. External debt becomes necessary when domestic financial resources become inadequate to finance public goods that increase welfare and engender economic growth. External debts are funds sourced from outside the nation's border usually in foreign currency and is interest- bearing to finance specific projects (ibid)

External debt has become one of the important sources of domestic capital. In particular, the dual-gap theory, that explains the savings gap and foreign exchange gap, has highlighted the motivation behind the introduction of external debt to a growth model. The savings gap and foreign exchange gap indicate that there are inadequate and insufficient resources to support the expected level of growth in the economy, revealing the role of external borrowings. Thus, the role of external borrowing in economic growth has been discovered even though it depends on the two gaps of either savings-investment or import-export. The foreign borrowing will increase until the gaps are narrowed and the expected marginal product of capital is equivalent to the marginal cost of funds.

External debt is mainly used to supplement the domestic sources of funds for supporting development and other needs of a country. Usually external debt is incurred by a country which suffers from shortages of domestic savings and foreign exchange need to achieve its developmental and other national objectives (Abu et al, 2015). However, if the external debt is not used in income-generating and productive activities, the ability of a debtor nation to repay the debt is significantly reduced. It is often argued that the excessive debt constitutes an obstacle to sustainable economic growth and poverty reduction (Berensmann, 2004; Maghyereh and Hashemite, 2003)

External debt is acquired in order to finance budget deficit and speed up economic activities; hence, external debt should result to economic growth of a nation. Countries can have heavy external debt along with relatively higher level of exports that may help to sustain their level of external debt. But external debt, if not sustainable, imposes higher risk to the economic prosperity, as its servicing which is also an indicator of higher current account deficit, may lead to debt overhang in a country (Shabbir, 2009).

The accumulation of external debt is a common phenomenon of the developing countries where domestic savings is low, current account payments deficits are high, and imports of capital are needed to augment domestic resources to accelerate economic growth and poverty reduction. This becomes effective as long as borrowed funds are properly utilized for productive investment, and do not suffer from macroeconomic instability, policies, that distort economic incentives (Amakom, 2003)

\subsection{Theoretical Review}

According to Shehu and Aliyu (2014), various theories have been propounded by scholars in an attempt to explain the subject of external debt. The theories include the dual gap analysis, debt overhang, liquidity constraint hypothesis. All these theories are applicable to Nigeria economy and they are explained below

The Dual Gap Analysis: This explains that development is a function of investment and that such investment which requires domestic savings is not sufficient to ensure that development take place. There must be the possibility of obtaining from abroad the amount that can be invested in any country with the amount that is saved. Furthermore, the domestic resources are to be supplemented from abroad, such as excess of import over export (i.e, $\mathrm{M}>\mathrm{E}$ ). Furthermore, if the domestic resources are to be supplemented from abroad, such as excess of import over export (i.e. $\mathrm{M}>\mathrm{E}$ ). $\mathrm{I}-\mathrm{S} \mathrm{M}-\mathrm{E}$ Hence, $\mathrm{I}-\mathrm{S}=\mathrm{M}-\mathrm{E}$ In national income accounting, an excess of investment over domestic saving is equivalent to excess surplus of import over export. Income $=$ consumption + import + savings Output $=$ consumption + export + investment Income $=$ output Then Investment - Saving $=$ Import - Export this is the basis of dual gap analysis. If the available domestic saving fall short of the level necessary to achieve the target rate of growth, a savings- investment gap is said to exist on a similar note, if the maximum import requirement needed to achieve the growth target is greater than the maximum possible level of export, then these is an export-import of origin exchange gap

Debt Overhang Theory: Debt overhang refers to a situation where the debt stock of a nation exceeds its future capacity to repay it. Such a country's debt stock exceeds its ability to repay. The economy is in bad shape and 
will continue to decline, because it results in less money spent on education, infrastructures and health. According to the debt overhang theory, when countries have higher external debt to GDP ratio, they may find relatively less funds available to provide an environment conducive for business and promote investment, which further deteriorate the current level of economic growth.

The Liquidity Constraint Hypothesis: This states that an increase in external debt servicing leaves less avenues for developing countries to service their debt, that, therefore, affect their ability to borrow further from external resources, putting pressure on domestic borrowing and leading to crowding out. Crowding out occurs when increased government borrowing, a kind of expansionary fiscal policy, reduces investment spending.

\subsection{Empirical Review}

Sulaiman and Azeez (2012) study the effect of external debt on the economic growth of Nigeria using gross domestic product as the endogenous variable measuring economic growth as a function of ratio of external debt to export, inflation and exchange rate proxy as the exogenous variable. Data were gathered covering 1970-2010. Analysis of data was done using the econometric technique of ordinary least square. The result showed that external debt has contributed positively to Nigeria economy. This was supported by Ezeabasili, Isu, and Mojekwu, (2011) who examine the relationship between Nigeria's external debt and economic growth between1975-2006, with an error correction approach. Error correction estimate revealed that external debt has negative relationship with economic growth in Nigeria. A similar research was done by Iya, Gabdo, and Aminu (2013) with the same result. Ogege and Ekpudu (2010) examined the impact of debt burden on the Nigerian economy using time series data from 1970-2007. Ordinary least square (OLS) was used to test the relationship between debt burden and growth of the Nigeria economy. The result showed a negative relationship between debt stocks of internal and external; and gross domestic product, meaning that an increase in debt stock will lead to a reduction on the growth rate of Nigerian economy

Udeh, Ugwu \& Onwuka (2016) study external debt and economic growth: the Nigeria experience from 1980-2013. The study used a secondary data and analyzed the data using ordinary least square. The study discovered that External Debt had a positive relationship with Gross Domestic Product at short run, but a negative relationship at long run. Peter, Meriel and Peter (2012) study the interplay between foreign aid, external debt and economic growth: Nigeria experience from 1970 to 2008. Secondary data were sourced and analyzed using multiple regressions. The study revealed that, external debt has a negative impact on economic growth of Nigeria. Ocampo (2004) proclaims that the external debt situation for number of low income countries, mostly in Africa has become extremely different. For these countries, even fill use of traditional mechanism of rescheduling and debt resection together with continued provision of confessional financing and purist of sound economic policies may not be sufficient to attain sustainable external debt levels within a reasonable period of time and without additional external support. Despite the efforts made by countries themselves and the commitment made by the international communities; they are failing behind in their endeavor to achieve the "Millennium Development Goals".

Asley (2002) opines that high level of external debt in developing country negatively impact their trade capacities and performance. Debt overhang affects economic reforms and stable monetary policies, export promotion and a reduction in certain trade barrier that will make the economy more market friendly and this enhances trade performance. Furthermore, debt decreases a government ability to invest in producing and marketing exports, building infrastructure, and establishing a skilled labour force. Muhtar (2004) also states that, the service of these debts have direct negative impact on economic development. He says "debt services encroach on resources needed for socio economic development and poverty reduction. It also contributed to negative net resources flow". Anyanwu (1997) was of the opinion that whole scale of white elephant development project in the country is the root cause of our external debt problems. He said instead of emphasis being placed on small rural development project so as to reverse the chaotic trend of urbanization and lessen the opportunity for corruption.

According to Nweke (1990) a correct analysis of external debt in a third world countries such as Nigeria must be replaced in the content of the country's forceful integration into the western structural and dominated world capitalist economy as a peripheral appendage that provide natural resources and cheap labour for the industrialization process in the west include lucrative markets for surplus of the advanced country's manufacturers and the advance countries get a very high cost of the manufactured product of the west. Ajayi and Oke (2012) study the effect of external debt on economic growth and development in Nigeria. Secondary data were sourced and analyzed using ordinary least square method of regression. The study revealed that external debt burden had an adverse effect on the nation income and per capital income of the nation. High level of 
external debt led to devaluation of the nation currency, increase in retrenchment of workers, continuous industrial strike and poor educational system. This led to the economy of Nigeria getting depressed.

\section{Methodology}

Data for this study were sourced from CBN Statistical Bulletin 2015 and data sourced were subjected to unit root co-integration, augmented dickey fuller to establish the stationary and non stationary of the data and to know if the data are spurious. The data were therefore analyzed using multiple regressions

\subsection{Model Specification and Estimation}

This study adopted a model from Ajayi and Oke (2012) and modified for the purpose of this study. The model specification is stated thus;

$$
\mathrm{GDP}=\mathrm{f}(\mathrm{DSP}, \mathrm{EDS}, \mathrm{CAPI}, \mathrm{EXR}, \mathrm{EXP})
$$

The new functional model for the study will be written as

$$
\mathrm{GDP}=\beta 0+\beta 1 \mathrm{DSP}+\beta 2 \mathrm{EDS}+\beta 3 \mathrm{EXR}+\beta 4 \mathrm{CAPI}+\beta 5 \mathrm{EXPP})
$$

The explicit form of Equation 1 is represented as follows;

$$
\begin{aligned}
& \begin{array}{ccccc}
\mathrm{n} & \mathrm{n} & \mathrm{n} & \mathrm{n} & \mathrm{n}
\end{array} \\
& \log G d p=\beta 0+\beta_{1} \log \sum D s p+\beta_{2} \log \sum E d s+\beta_{3} \log \sum C a p i+\beta_{4} \log \sum E x r+\beta_{5} \log \sum E x p p+\mu i \\
& t=1 \quad t=1 \quad t=1 \quad t=1 \quad t=1
\end{aligned}
$$

Where;

$\beta 0=$ Constant term

GDP $=$ Gross Domestic Products

DSP $=$ Debt Service Payments

EDS $=$ External Debt Stocks

EXR $=$ Exchange Rate

CAPI $=$ Capital Investment

$\mathrm{EXPP}=$ Export

$\mu=$ Error Term

$\beta 1, \beta 2, \beta 3, \beta 4, \beta 5$, parameters to be estimated

The apriori expectations for the coefficients are as follows:

$$
\beta 0>0 ; \beta 1>0 ; \beta 2>0 ; \beta 3>0 ; \beta 4<0 ; \beta 5<0
$$

\section{Findings and Interpretation of Results}

The study estimated a model for the impact of foreign borrowing on the economic growth of Nigeria by making use of time-series data covering a period of 30years from 1985 to 2014.

\subsection{Unit Root Tests Results}

Table 1. Augmented Dickey-Fuller unit root test for the variables

\begin{tabular}{lllll}
\hline Variables & ADF & $\mathbf{5 \%}$ & Differencing & LAGS \\
\hline $\log$ GDP & 5.4441 & 0.0001 & $2^{\text {nd }}$ & 1 \\
\hline $\log$ DSP & 6.8731 & 0.0000 & $2^{\text {nd }}$ & 1 \\
\hline $\log$ EDS & 3.7276 & 0.0091 & $2^{\text {nd }}$ & 1 \\
\hline $\log$ EXR & 4.6339 & 0.0010 & $2^{\text {nd }}$ & 1 \\
\hline $\log$ CAP & 5.5182 & 0.0001 & $2^{\text {nd }}$ & 1 \\
\hline $\log$ EXP & 7.4737 & 0.0000 & $2^{\text {nd }}$ & 1 \\
\hline
\end{tabular}

Source: Author computation from Eviews 7

Table 1 show the Augmented Dickey-Fuller unit root test for the variables so as to verify if the variables are 
stationary or not. The findings of the results revealed that the variables are stationary and does not have a unit root problem at $5 \%$, second differencing and at lag 1 within the period considered.

4.1.2 Analysis of Co-integration Test Results

Table 2. Johansen's Multivariate Co-integration test

\begin{tabular}{llllllll}
\hline $\begin{array}{l}\text { Hypothesized } \\
\text { No. of CE(s) }\end{array}$ & Eigen-value & $\begin{array}{l}\text { Trace } \\
\text { Statistic }\end{array}$ & $\begin{array}{l}\text { 0.05 } \\
\text { Critical } \\
\text { Value }\end{array}$ & Prob.** & $\begin{array}{l}\text { Max-Eigen } \\
\text { Statistic }\end{array}$ & $\begin{array}{l}\text { 0.05 } \\
\text { Critical } \\
\text { Value }\end{array}$ & Prob.** \\
\hline None* & 0.8897 & 182.1703 & 95.7537 & 0.0000 & 59.5310 & 40.0776 & 0.0001 \\
\hline At Most 1* & 0.7808 & 122.6393 & 69.8189 & 0.0000 & 40.9836 & 33.8769 & 0.0060 \\
\hline At Most 2* & 0.7182 & 81.6557 & 47.8561 & 0.0000 & 34.1926 & 27.5843 & 0.0061 \\
\hline At Most 3* & 0.6250 & 47.4632 & 29.7971 & 0.0002 & 26.4802 & 21.1316 & 0.0080 \\
\hline At Most 4* & 0.4807 & 20.9829 & 15.4947 & 0.0067 & 17.6898 & 14.2646 & 0.0138 \\
\hline At Most 5 & 0.1148 & 3.2931 & 3.8415 & 0.0696 & 3.2931 & 3.8415 & 0.0696 \\
\hline
\end{tabular}

Source: Author computation from Eviews 7

The Table 2 shows the Johansen's Multivariate Co-integration test of the variables used in this research study. Details of the result are shown in the appendix section. Based on the hypothesized number of co-integrated equation(s), it is revealed that both the Trace and Max-Eigen statistic test has five co-integrating equation because their p-value is lesser than the test of significance at 5\%; we therefore reject the null hypothesis and conclude that there is five co-integrating equation between the variables.

Table 3. Least square multiple regression

\begin{tabular}{|c|c|c|c|c|}
\hline \multicolumn{5}{|c|}{$\begin{array}{l}\text { Dependent Variable: LOGGD } \\
\text { Method: Least Squares } \\
\text { Date: 11/07/16 Time: 10:35 } \\
\text { Sample: } 19852014 \\
\text { Included observations: } 30\end{array}$} \\
\hline Variable & Coefficient & Std. Error & t-Statistic & Prob. \\
\hline LOGDSP & 0.291830 & 0.102620 & 2.843787 & 0.0090 \\
\hline LOGEDS & -0.076584 & 0.101463 & -0.754794 & 0.4577 \\
\hline LOGEXR & 0.033406 & 0.168569 & 0.198173 & 0.8446 \\
\hline LOGCAP & 0.592362 & 0.088480 & 6.694847 & 0.0000 \\
\hline LOGEXP & 0.457788 & 0.127067 & 3.602738 & 0.0014 \\
\hline $\mathrm{C}$ & 3.070217 & 0.492737 & 6.230942 & 0.0000 \\
\hline R-squared & 0.986299 & \multicolumn{2}{|c|}{ Mean dependent var } & 8.398667 \\
\hline Adjusted R-squared & 0.983445 & \multicolumn{2}{|c|}{ S.D. dependent var } & 2.002384 \\
\hline S.E. of regression & 0.257639 & \multicolumn{2}{|c|}{ Akaike info criterion } & 0.302345 \\
\hline Sum squared resid & 1.593073 & \multicolumn{2}{|c|}{ Schwarz criterion } & 0.582584 \\
\hline Log likelihood & 1.464830 & \multicolumn{2}{|c|}{ Hannan-Quinn criter. } & 0.391996 \\
\hline F-statistic & 345.5470 & \multirow{2}{*}{\multicolumn{2}{|c|}{ Durbin-Watson stat }} & 1.958316 \\
\hline $\operatorname{Prob}(F-$-statistic) & 0.000000 & & & \\
\hline
\end{tabular}

Source: Author computation from Eview 7 


\subsubsection{Interpretation of Results}

The Determinant of Multiple Regressions $\left(R^{2}\right)$

The determinant of multiple regression $\left(R^{2}\right)$ stood at approximately 0.9863 , which indicates that a change in the gross domestic product is explained to the tune of $98.63 \%$ by the independent variables (DSP, EDS, EXR, CAP) while $1.37 \%$ variation remains unexplained. The adjusted $R^{2}$ of approximately $98.34 \%$ shows that $R^{2}$ indicates the true behaviour of the dependent variable (GDP) according to change in independent variables.

\subsubsection{Test of Significance of the Parameter Estimates}

The standard error test and student's t-test were used to establish the significance of the parameter estimates.

\subsection{Standard Error Test}

To determine the significance of the parameter estimate, half of each coefficient is compared with its standard errors. The result of the standard error test is presented in Table 4.

Table 4. Results of the standard error test

\begin{tabular}{llllll}
\hline $\begin{array}{l}\text { Dependent } \\
\text { variable }\end{array}$ & $\begin{array}{l}\text { Explanator } \\
\mathbf{y} \text { variables }\end{array}$ & $\begin{array}{l}\text { Absolute } \\
\text { Coefficient } \\
\left(\widehat{\boldsymbol{b}}_{\boldsymbol{\imath}}\right)\end{array}$ & $\begin{array}{l}\text { Standard } \\
\text { error }\left(\widehat{\boldsymbol{s}}_{\boldsymbol{\imath}}\right)\end{array}$ & $\begin{array}{c}\text { Implication } \\
\mathbf{1} / \mathbf{2} \widehat{\boldsymbol{b}}_{\boldsymbol{\imath}}>s \widehat{\boldsymbol{b}}_{\boldsymbol{\imath}}\end{array}$ & Decision \\
\hline \multirow{3}{*}{$\operatorname{logGDP}$} & Constant & 3.07 & 0.49 & $1.54>0.49$ & Significant \\
\cline { 2 - 6 } & $\operatorname{logDSP}$ & 0.29 & 0.10 & $0.15>0.10$ & Significant \\
\cline { 2 - 6 } & $\operatorname{logEDS}$ & 0.08 & 0.10 & $0.04<0.10$ & Not Significant \\
\cline { 2 - 6 } & $\operatorname{logEXR}$ & 0.03 & 0.17 & $0.02<0.17$ & Not Significant \\
\cline { 2 - 6 } & $\log \mathrm{CAP}$ & 0.59 & 0.09 & $0.30>0.09$ & Significant \\
\cline { 2 - 6 } & $\operatorname{logEXP}$ & 0.45 & 0.13 & $0.23>0.13$ & Significant \\
\hline
\end{tabular}

Source: Author computation from Eview 7.

From the table above, it could be observed that our regression estimate is statistically significant except for EDS and EXR that are not statistically significant different from zero on variation in GDP, at 5\% level of significance, using a two-tail test. The implication of the result is that as debt service payment increase, it leads to increase in capital investment which occurs as a result of increase in export within the period considered.

\subsubsection{Student's T-test}

The summary of the results of student's t-test of significance of the parameter estimates is presented below. Since the alternative hypothesis is expressed in the form of $b_{i} \neq 0$, we used a two-tail critical region. Each tail correspond half of the chosen level of significance; the area of each tail is $0.25(25 \%)$.

The degree of freedom: $N-K=30-5=25$

Where:

$\mathrm{K}=$ Number of parameter estimates;

$\mathrm{N}=$ number of observation

To find out the statistical significance of the variables, we compare the $t_{c a l}$ of each variable with the $t_{t a b}$ as analysed below: 
Table 5. Results of the student's t-test

\begin{tabular}{llllll}
\hline $\begin{array}{l}\text { Dependent } \\
\text { variable }\end{array}$ & $\begin{array}{l}\text { Explanator } \\
\mathbf{y} \text { variable }\end{array}$ & $\begin{array}{l}\text { Absolute } \\
\boldsymbol{t}_{\boldsymbol{c a l}}\end{array}$ & $\begin{array}{l}\boldsymbol{t}_{\boldsymbol{t a b}} \text { at } \mathbf{5 \%} \\
\text { critical value }\end{array}$ & $\begin{array}{l}\text { Implication } \\
\text { (based on } \\
\text { absolute value) }\end{array}$ & Decision \\
\hline $\log \mathrm{GDP}$ & Constant & 6.23 & 2.060 & $6.23>2.060$ & Significant \\
\cline { 2 - 6 } & $\operatorname{logDSP}$ & 2.84 & 2.060 & $2.84>2.060$ & Significant \\
\cline { 2 - 6 } & $\operatorname{logEDS}$ & 0.75 & 2.060 & $0.75<2.060$ & Not Significant \\
\cline { 2 - 6 } & $\operatorname{logEXR}$ & 0.20 & 2.060 & $0.20<2.060$ & Not Significant \\
\cline { 2 - 6 } & $\log \mathrm{CAP}$ & 6.69 & 2.060 & $6.69>2.060$ & Significant \\
\cline { 2 - 6 } & $\operatorname{logEXP}$ & 3.60 & 2.060 & $3.60>2.060$ & Significant \\
\hline
\end{tabular}

Source: Author computation from Eview 7.

\subsubsection{Decision Rule for Implication}

If $\mathrm{t}_{\text {cal }}$ is greater than the $\mathrm{t}_{\mathrm{tab}}$ at $5 \%$ significance level, reject $\mathrm{H}_{0}$, otherwise, accept $\mathrm{H}_{1}$

From Table 5, only DSP, CAP and EXP are statistically significant in explaining the variation in GDP at 5\% level of significance.

\subsubsection{The F-Distribution Test Result}

The result of ' $\mathrm{F}$ ' distribution test with $v_{1} a n d v_{2}$ degree of freedom at $5 \%$ significant level for the model are shown in Table 4.3

To estimate $F_{t a b}$ :

$$
\begin{gathered}
v_{1}=K-1=5-1=4 \\
v_{2}=N-K=30-5=25
\end{gathered}
$$

From the statistical table, $v_{1} / v_{2}$ is 2.28

Table 6. Result of 'F' distribution test

\begin{tabular}{rllll}
\hline $\boldsymbol{F}_{\boldsymbol{c a l}}$ & $\boldsymbol{F} \boldsymbol{t a b}$ & Prob. & Implication & Decision \\
\hline 345.55 & 2.76 & 0.00 & $345.55>2.76$ & $H_{0}$ is rejected \\
\hline
\end{tabular}

Source: Author computation from E-view 7

From the above table, the $f \mathrm{cal}(345.55)$ is greater than $f \operatorname{tab}(2.76)$; this is a clear indication that the whole regression is statistically significant due to the overriding effect of debt service payments, capital investment and export. Hence, the overall null hypothesis is rejected and the alternative hypothesis is accepted which indicates that there is significant impact of foreign borrowing on the economic growth of Nigeria within the period considered.

\subsubsection{Durbin-Watson Test of Autocorrelation}

Using amended Durbin-Watson test at 5\% critical values. The following results were obtained:

$\mathrm{N}=30$ (Number of observed years)

$\mathrm{K}=5$ (Number of explanatory variables)

$$
\begin{gathered}
d l=0.832, d u=1.521 \\
d u<d l
\end{gathered}
$$

Hence, the null hypothesis is rejected indicating that there is statistical evidence that the error terms are positively auto-correlated. 
Table 7. Result of autocorrelation test

\begin{tabular}{llllll}
\hline $\begin{array}{l}\text { Durbin-Watson } \\
\text { calculated }\left(\mathbf{d}^{*}\right)\end{array}$ & $\begin{array}{l}\text { Lower limit of } \\
\text { observed } \\
\text { Durbin-Watson }\left(\mathbf{d}_{\mathbf{L}}\right)\end{array}$ & $\begin{array}{l}\text { Upper limit of } \\
\text { observed } \\
\text { Durbin-Watson }\left(\mathbf{d}_{\mathbf{U}}\right)\end{array}$ & $\boldsymbol{d} \boldsymbol{u}>d L$ & Decision \\
\hline 1.95 & 0.832 & 1.521 & Yes & Reject $\mathrm{H}_{0}$ \\
\hline
\end{tabular}

Source: Author computation from Eview 7

The Durbin-Watson value of 1.95 indicated the presence of autocorrelation of the first order among the residuals of the model. This implies that any shock arising from the Nigeria economy as a result of foreign borrowing, do not disappear instantaneously but extends into the next periods.

\subsection{Hypotheses Interpretation}

$\mathbf{H}_{01}$ : There is no significant impact of external borrowing on economic growth in Nigeria

$\mathbf{H}_{1 \mathrm{~A}}$ : There is significant impact of external borrowing on economic growth in Nigeria

The first hypothesis is tested using the overall test of statistic, F-statistic. The findings revealed that the p-value (0.00) of the calculated F-statistic (345.55) is lesser than the test of significant at 5\% due to the overriding significant effect of DSP, CAP and EXP respectively. We therefore reject $\mathbf{H}_{\mathbf{0 1}}$ and conclude that there is significant impact of external borrowing on economic growth in Nigeria within the period considered. This is in agreement with the research study of Ajayi and Oke (2012) that foreign borrowing had an adverse effect on the nation income and per capital income of the nation based on the considered significant variables in the study.

$\mathbf{H}_{\mathbf{0 2}}$ : There is no significant relationship between external borrowing and capital investment in Nigeria

$\mathbf{H}_{\mathbf{2 A}}$ : There is significant relationship between external borrowing and capital investment in Nigeria

The second hypothesis is tested using t-statistic. The analysis revealed that the p-value $(0.00)$ of the calculated t-statistic (6.69) is lesser than the test of significant at 5\%; we therefore reject $\mathbf{H}_{\mathbf{0 2}}$ and conclude that there is significant relationship between external borrowing and capital investment in Nigeria within the period considered. This is in agreement with the research study of Chigbu et al., (2015) that external borrowing have significant and positive impact on capital investment in Nigeria.

$\mathbf{H}_{03}$ : There is no significant effect of debt service payment on economic growth in Nigeria

$\mathbf{H}_{3 \mathrm{~A}}$ : There is significant effect of debt service payment on economic growth in Nigeria

The third hypothesis is tested using t-statistic. The analysis revealed that the p-value $(0.01)$ of the calculated t-statistic (2.84) is lesser than the test of significant at 5\%; we therefore reject $\mathbf{H}_{\mathbf{0 3}}$ and conclude that there is significant effect of debt service payment on economic growth in Nigeria within the period considered. This is not in agreement with the research work of Uma, Eboh, and Obidike (2013) that debt service payment is inversely related to economic growth but at an insignificant level.

\section{Conclusion}

The study examined foreign borrowing and its impact on the economic growth of the developing nations using Nigeria as a case study. Foreign borrowing is essential to the growth of the developing countries because most of these countries are consuming nations and lack the ability to save or invest; to be able to close these gaps, it becomes imperative for them to borrow. Borrowing is good but when the country borrows and channels same for a wrong purpose or diverts most of the funds to private pockets or is mismanaged and mismatched, it becomes a problem for the country to service her debt and at the same time affects the required growth expected. $\mathrm{Be}$ as it may, the study conclude that the impact of foreign borrowing is not positively felt in Nigeria due to the fact that the funds are not always channeled to the real productive sectors and not well monitored. Therefore, it is recommended that the purpose of the borrowing should be considered important while channeling the funds. Efficient utilization of the funds to solve the purpose by which it was acquired will go a long way to impact growth on the economy of a country. Without solving the infrastructural deficit in Nigeria, diversification of economy from mono product to others such as mining, agricultural and textile becomes a mirage. Therefore, government should channel these borrowing to solve the infrastructural deficit of the country so as to witness more growth in the economy. To increase the level of our exportation, government must partner with private organizations and encourage the local producers by channeling these borrowing to them so as to enhance the increment in their products and its standardization so as to enhance economic growth in the country 


\section{References}

Abu, S., Selvanathan, E., \& Saroja, S. (2015). The Impact of External Debt on Economic Growth: Empirical Evidence from Highly Indebted Poor Countries. The University of Western Australia. Discussion Paper 15(10), 1-33.

Ajayi, L. B., \& Oke, M. O. (2012). Effect of External Debt on Economic Growth and Development of Nigeria. International Journal of Business and Social Science, 3(12), 297-302.

Amakom, U. S. (2003). Nigeria Public Debt and Economic Growth: An Empirical Assessment of Effects on Poverty. African Institute for Applied Economics, 320-325.

Anyanwu, A. (1997). The Structure of Nigerian Economy. Ibadan: Ibadan University Press.

Arnone, M., Bandiera, L., \& Presbiteno, A. (2005). External Debt Sustainability: Theory and Empiricalevidence. Retrieved from http://www.unicatt.it/dipartimenti/DISES/allegati/arnoneBandierapresbite ro.pdf

Asley, A. (2002). Argued that Debt Burden is not a Problem of Freely Resource to Debt Services Payment. Principle of International Finance, 1, 142-147. Forthright Educational Publishers (A Division of Forthright Consult Limited) Lagos.

Ayadi, F. S., \& Ayadi, F. O. (2008). The Impact of External Debt on Economic Growth: A Comparative Study of Nigeria and South Africa. Journal of Sustainable Development in Africa, 10(3), 234-264.

Berensmann, K. (2004). New Ways of Achieving Debt Sustainability beyond the Enhanced HIPC Initiatives. Inter Economics, 39(6), 321-330.

Bureau of Statistic. (2005). Nigeria Statistic Fact Sheet on Economic Social and Development. 31-32.

Chenery, H. B., \& Stout, A. (1966). Foreign Assistance and Economic Development. American Economic Review, 55(2), 679-733.

Chigbu, E. E., Ubah, C. P., \& Chigbu, U. S. (2015). Impact of Capital Inflows on Economic Growth of Developing Countries. International Journal of Management Science and Business Administration, 1(7), $7-21$.

Edun, A. O., Akinde, J. O, Olaleye, S. O., \& Idowu, G. A. (2013). Infrastructural Development and Its Effect on Economic Growth: The Nigerian Perspective. European Scientific Journal, 9(31), 431-451.

Ezeabasili, V. N., Isu, H. O., \& Mojekwu, J. N. (2011). Nigeria's External Debt and Economic Growth: An Error correction Approach. International Journal of Business and Management, 6(5), 1833-1844.

Falegan, S. B. (1978). Nigeria External Debt Burden. CBN Economic and Financial Review, 30(2).

Iya, I., Gabdo, O., \& Aminu, U. (2013). An Empirical Investigation into the Impact of External Debt on Economic Growth in Nigeria. International Journal of Current Research, 2(1), 55-60.

Manghyereh, A., \& Hashemite, U. (2003). External Debt and Economic Growth in Jordan; the Threshold Effect. Economina Internationale/International Economics, 56(3), 337-355.

Muhtar. (2004). Weak External Demand for Philippine Export is Dampening Growth National.

Nwankwo, A. (2016, November 1). Nigeria Badly Needs \$29.8Billion for Infrastructure Development in Nigeria, Greenbarge Reporters. Retrieved from www.greenbreporters.com/home/business/banking

Nweke, C. (1990). The Origin and Dimension of Nigeria External Debt in Nigeria External Debt Crisis Its Management, pp. 42-61. Malthous Press Ltd.

Ocampo, B. (2004). Utilized Ordinary Least Square for each of the Thirteen Less Developed Countries over the Sample Period 1965-1990.

Ogege, S., \& Ekpudu, J. E. (2010).The Effect of Debt Burden on the Nigerian Economy. Journal of Research in National Development, 8(2).

Oloyede, J. A. (2002). Principles of International Finance. Forthright Educational Publishers Ltd.

Olufemi, A. O. (2016). Infrastructure Development and Financing Approaches in Developing Nations: Constraints and Opportunities. Journal of Advances in Mathematics and Computer Science and their Applications, 1(3), 235-251.

Peter, N., Meriel, A., \& Peter, S. (2012). Interplay of Foreign Aid, External Debt and Economic Growth: The Nigeria Experience. International Journal of Economics and Finance, 4(8). 
Shabbir, S. (2009). Does External Debt Affect Economic Growth. Evidence from Developing Countries. Retrieved October 3, 2016, from http://aysps:gsu.edu/ECON_MA_shabbirs.pdf

Shehu, U., \& Aliyu, M. (2014). External Debt and Economic Growth: Evidence from Nigeria. Journal of Economics and Sustainable Development, 5(18).

Soludo, C. (2003). Debt Poverty and Inequality. In Okojo Iweala, Soludo, and Muntar (Eds.), The Debt Trap in Nigeria (pp. 23-74). NJ: African World Press.

Sulaiman, L. A., \& Azeez, B. A. (2012). Effect of External Debt on Economic Growth of Nigeria. Journal of Economics and Sustainable Development, 3(8).

Udeh, S., Ugwu, J., \& Onwuka, I. (2016). External Debt and Economic Growth: Nigeria Experience. European Journal of Accounting Auditing and Finance Research, 4(2), 33-48.

Uma, K. E., Eboh, F. E., \& Obidike, P. C. (2013). Debt and Debt Service: Implications on Nigerian Economic Development. Asian Journal of Social Sciences \& Humanities, 2(2), 275-284.

\section{Appendix}

Independent and Dependent Variables With Their Figures From 1985-2014

\begin{tabular}{|c|c|c|c|c|c|c|}
\hline Years & $\begin{array}{l}\text { EDS } \\
\text { (N'Billion) }\end{array}$ & $\begin{array}{l}\text { CAP } \\
\text { I(N'Billion)B }\end{array}$ & $\begin{array}{l}\text { GDP } \\
\text { (N'Billion) }\end{array}$ & $\begin{array}{l}\text { DSP } \\
\text { (N'Billion) }\end{array}$ & EXR & $\begin{array}{l}\text { EXP } \\
\text { (N'Billion) }\end{array}$ \\
\hline 1985 & 17.30 & 5.46 & 134.59 & 1.61 & 1 & 5.02 \\
\hline 1986 & 41.45 & 8.53 & 134.60 & 1.63 & 2 & 2.76 \\
\hline 1987 & 100.79 & 6.37 & 193.13 & 3.93 & 4 & 6.49 \\
\hline 1988 & 133.96 & 8.34 & 263.29 & 9.24 & 5 & 5.32 \\
\hline 1989 & 240.39 & 15.03 & 382.26 & 13.27 & 7 & 10.66 \\
\hline 1990 & 298.61 & 24.05 & 472.65 & 23.82 & 8 & 10.87 \\
\hline 1991 & 328.45 & 28.34 & 545.67 & 26.41 & 10 & 11.42 \\
\hline 1992 & 544.26 & 39.76 & 875.34 & 19.40 & 17 & 10.99 \\
\hline 1993 & 633.14 & 54.50 & $1,089.68$ & 81.08 & 22 & 5.34 \\
\hline 1994 & 648.81 & 70.92 & $1,399.70$ & 49.40 & 22 & 4.4 \\
\hline 1995 & 716.87 & 121.14 & $2,907.36$ & 51.06 & 22 & 10.21 \\
\hline 1996 & 617.32 & 212.93 & $4,032.30$ & 53.05 & 22 & 11.28 \\
\hline 1997 & 595.93 & 269.65 & $4,189.25$ & 68.54 & 22 & 14.96 \\
\hline 1998 & 633.02 & 309.02 & $3,989.45$ & 64.39 & 22 & 9.5 \\
\hline 1999 & $2,577.37$ & 498.03 & $4,679.21$ & 30.84 & 93 & 12.15 \\
\hline 2000 & $3,097.38$ & 239.45 & $6,713.57$ & 131.05 & 102 & 24 \\
\hline 2001 & $3,176.29$ & 438.70 & $6,895.20$ & 155.42 & 112 & 20.06 \\
\hline 2002 & $3,932.88$ & 321.38 & $7,795.76$ & 163.81 & 121 & 21.26 \\
\hline 2003 & $4,478.33$ & 241.69 & $9,913.52$ & 363.51 & 129 & 26.92 \\
\hline 2004 & $4,890.27$ & 351.25 & $11,411.07$ & 382.50 & 134 & 26.49 \\
\hline 2005 & $2,695.07$ & 519.47 & $14,610.88$ & 393.96 & 132 & 35.53 \\
\hline 2006 & 451.46 & 552.39 & $18,564.59$ & 249.33 & 129 & 62.7 \\
\hline 2007 & 438.89 & 759.28 & $20,657.32$ & 213.73 & 126 & 56.14 \\
\hline 2008 & 523.25 & 960.89 & $24,296.33$ & 381.20 & 119 & 82.98 \\
\hline 2009 & 590.44 & $1,152.80$ & $24,794.24$ & 251.79 & 149 & 52.15 \\
\hline
\end{tabular}




\begin{tabular}{lllllll}
\hline 2010 & 689.84 & 883.87 & $54,612.26$ & 415.66 & 150 & 93.24 \\
\hline 2011 & 896.85 & 918.55 & $62,980.40$ & 527.18 & 154 & 129 \\
\hline 2012 & $1,026.90$ & 874.84 & $71,713.94$ & 679.30 & 157 & 144.92 \\
\hline 2013 & $1,373.58$ & $1,108.39$ & $80,092.56$ & 828.10 & 157 & 92.95 \\
\hline 2014 & $1,631.52$ & $2,681.08$ & $89,043.62$ & 941.70 & 157.3 & 104.83 \\
\hline 2015 & 2111.53 & 1496.71 & $94,144.96$ & 1060.60 & 193.27 & 602.1 \\
\hline
\end{tabular}

Source: CBN Statistical Bulletin of various Editions.

\section{Copyrights}

Copyright for this article is retained by the author(s), with first publication rights granted to the journal.

This is an open-access article distributed under the terms and conditions of the Creative Commons Attribution license (http://creativecommons.org/licenses/by/4.0/). 